\title{
Monthly consumptive use of rice in the semiarid and humid regions of Puerto Rico'
}

\author{
Megh R. Goyal and Eladio A. Gonzálezz
}

\begin{abstract}
ABSTRACI
Monthly consumptive use of water $(\mathrm{CU}, \mathrm{mm})$ by rice was estimated with modified Blaney-Criddle model, Hackbart's computer pragram and available climatic data in the semiarid south coast (Lajas) and humid north coast (Arecibo) of Puerto Rico. Twelve planting dates and three crop lengths of 90, 105 and 120 days were considered. For 120 days and 12 planting dates, total consumptive use varied from 442 to $589 \mathrm{~mm}$ af Arecibo, compared with $\mathbf{4 2 8}$ to $579 \mathrm{~mm}$ at Lajas. Average total $\mathrm{CU}(\mathrm{mm})$ was 392 for 90 days, 458 for 105 days, 514 for 120 days at Arecibo, compared with 382 for 90 days, 447 for 105 days and 502 for 120 days at Lajas. Daily CU (mm/day) range was 4.3 to 4.4 at Arecibo, compared with 4.2 to 4.3 at Lajas.
\end{abstract}

\section{RESUMEN}

Consumo de agua del arroz en las regiones semiáridas y húmedas de Puerto Rico

Se estimó el uso consuntivo (UC) del arroz, utilizando el modelo madificado de Blaney-Criddle, el programa computarizado de Hackbart y los datos climatológicos disponibles. El estudio se llevó a cabo en la costa semiárida del sur (Lajas) y en la húmeda del norte (Arecibo), Puerto Rico. Se utilizaron 12 fechas de siembra y tres períodos en el campo: 90, 105 y 120 días. Para el períado de 120 días y 12 fechas de siembra, el UC total fluctuó de 442 a $589 \mathrm{~mm}$. en Arecibo y de 428 a $579 \mathrm{~mm}$. en Lajas. El UC (mm./día) fluetuó de $\mathbf{4 . 3}$ a 4.4 en Arecibo y de $\mathbf{4 . 2}$ a 4.3 en Lajas. Para el período de 120 días el promedio de UC fue $514 \mathrm{~mm}$. en Arecibo y 502 mm. en Lajas.

\section{INTRODUCTION}

The rice plant usually takes 3-6 months from germination to maturity, depending on the variety and loeation (9). The life history of rice consists of three growth stages: vegetative (germination to initiation of panicle primordia), reproductive (panicle primordia initiation to heading) and ripening (heading to maturity). A 120-day variety in the tropies spends about 60 days in the vegetative growth, 30 days in the reproductive stage, and 30 days in the ripening period $(3,4,9)$. Direct seeded rice

Manuscript submitted to Editorial Board 10 May 1988.

This study was conducted under C411, "Bioclimate of Puerto Rico" and USDA Grant No. 85-CSRS-2-2664, project CBAG-23, "Irrigation requirement estimations in Puerto Rico".

${ }^{2}$ Associate Agricultural Engineer and Research Assistant (Agronomy), Agricultural Experiment Station, University of Puerto Rico - Mayagïez Campus, Rio Piedras, P. R. 
Table 1.-Factors affecting monthly net irrigotion requirements of rice in semiarid and humid regions of Puerto Rico

\begin{tabular}{|c|c|c|c|}
\hline & Description & Arecibo & Lajas \\
\hline \multirow[t]{7}{*}{ I. } & Geographical faetors & & \\
\hline & Weather station no. & $66-0410$ & $66-5097$ \\
\hline & Location & Arecibo & Lajas \\
\hline & Latitude & $18^{\circ} 28^{\prime} \mathrm{N}$ & $18^{\circ} 09^{\prime} \mathrm{N}$ \\
\hline & Longitude & $66^{\circ} 42^{\prime} \mathrm{W}$ & $67^{\circ} 03^{\prime} \mathrm{W}$ \\
\hline & Elevation above gea lovel & $4.5 \mathrm{~m}$ & $27.0 \mathrm{~m}$ \\
\hline & Climatic zone & Humid, north eoast & Semiarid \\
\hline \multirow[t]{5}{*}{ II. } & Soil factors & & \\
\hline & Soil pH & 5.0 & 6.0 \\
\hline & Soil type & Toa soil (Mollisol) & $\begin{array}{l}\text { Fraternidad clay } \\
\text { (Vertisols) }\end{array}$ \\
\hline & Field eapacity & & \\
\hline & (AWC) depth & $9.0 \mathrm{~cm}$ & $9.0 \mathrm{~cm}$ \\
\hline \multirow[t]{16}{*}{ III. } & Management factors & & \\
\hline & Root depth & $60 \mathrm{~cm}$ & $60 \mathrm{~cm}$ \\
\hline & Allowable depletion & $50 \%$ & $50 \%$ \\
\hline & Initial soil moisture & $4.5 \mathrm{~cm}$ & $4,5 \mathrm{~cm}$ \\
\hline & Net irrigation application & $4.5 \mathrm{~cm}$ & $4.5 \mathrm{~cm}$ \\
\hline & Humid area factor & 0.8 & 0.8 \\
\hline & ET model, Blaney-Criddle & Yes & Yes \\
\hline & Irrigation method & Flood & Flood \\
\hline & Irrigation effieiency & $30 \%$ & $80 \%$ \\
\hline & Soll moisture at end of season & $4.5 \mathrm{~cm}$ & $4.5 \mathrm{~cm}$ \\
\hline & Irrigation for plant establishment & $20 \mathrm{~cm}$ & $20 \mathrm{~cm}$ \\
\hline & Land preparation & Dry & Dry \\
\hline & Planting & Broadeast & Broadeast \\
\hline & Crop duration, days & 90,105 or 120 & 90,105 or 120 \\
\hline & Cut off irrigation & 8 weeiks hefore harvest & 8 weeks before harvest \\
\hline & Drainage water & Recycled & Recycled \\
\hline
\end{tabular}

normally starts tillering earlier than transplanted rice, and transplanted rice usually takes about 1 week more to mature (9). Delayed transplanting can reduce plant height, dry matter production and fertile grains per panicle (9). Lozano and Abruña (3) evaluated effects of bimonthly plantings on medium-grain rice and found highest yields for February plantings and lowest yields for Oetober plantings at Gurabo Agricultural Substation, Puerto Rico. Crop season varied from 96 to 129 days depending on the variety and planting date (3). Vicente-Chandler et al. (8) estimated an area of 20,000 ha suited to rice production with two crops yearly in Puerto Rico and recommended irrigation of only 50 to $60 \%$ of the area at a given time.

Yoshida (9) indicated that in general 7 to $15 \mathrm{~mm} /$ day of irrigation depth is necessary after stand establishment to achieve the maximum 
TABLE 2.-Net irrigation requirements (inches per month) with modified Blaney-Criddle method. Crop: Rice. Location: Arecibo

\begin{tabular}{|c|c|c|c|c|c|c|c|c|c|c|c|c|c|c|c|c|c|}
\hline $\begin{array}{l}\text { Planting to } \\
\text { last harvest. }\end{array}$ & Days & Paramet & & Jan & Feb & Mar & April & May & June & July & Aug & Sept & Oet & Nov & Dec & Total & $\begin{array}{c}\text { Gross } \\
\text { irrigation }\end{array}$ \\
\hline January 1 & & $\mathbf{C U}$ & in & 3.97 & 4.63 & 4.71 & & & & & & & & & & 13.31 & \\
\hline & 90 & ER, & in & 0.84 & 1.02 & 0.95 & & & & & & & & & & 2.82 & Flood \\
\hline March 31 & & NIR, & in & 3.13 & 3.60 & 3.76 & & & & & & & & & & 10.50 & 35.0 \\
\hline February & & CU, & in & & 3.06 & 5.50 & 4.95 & & & & & & & & & 13,50 & \\
\hline to & 89 & ER, & in & & 1.19 & 0.99 & 1.62 & & & & & & & & & 3.80 & \\
\hline April 30 & & NIR, & in & & 1.87 & 4.51 & 3.33 & & & & & & & & & 9.70 & 32.3 \\
\hline March 1 & & $\mathrm{CU}$, & in & & & 3.98 & 5.76 & 5.77 & & & & & & & & 15.50 & \\
\hline to & 92 & ER, & in & & & 0.96 & 1.70 & 1.91 & & & & & & & & 4.56 & \\
\hline May 31 & & NIR, & in & & & 3.02 & 4.06 & 3.86 & & & & & & & & 10.94 & 36.5 \\
\hline April 1 & & $\mathrm{CU}$ & in & & & & 3.95 & 6.74 & 5.97 & & & & & & & 16.65 & \\
\hline to & 91 & ER, & in & & & & 1.24 & 2.01 & 1.66 & & & & & & & 4.92 & \\
\hline June 30 & & NIR, & in & & & & 2.70 & 4.72 & 4.31 & & & & & & & 11.73 & 39.1 \\
\hline May 1 & & $\mathrm{CU}$, & in & & & & & 4.84 & 7.01 & 5.89 & & & & & & 17.74 & \\
\hline to & 92 & ER, & in & & & & & 1.71 & 1.76 & 1.47 & & & & & & 4.95 & \\
\hline July 31 & & NIR, & in & & & & & 3.13 & 5.25 & 4.41 & & & & & & 12.80 & 42.7 \\
\hline June 1 & & $\mathrm{CU}$ & in & & & & & & 4.76 & 6.92 & 5.78 & & & & & 17.46 & \\
\hline to & 92 & ER, & in & & & & & & 1.67 & 1.56 & 1.58 & & & & & 4.81 & \\
\hline August 31 . & & NIR, & in & & & & & & 3.09 & 5.36 & 4.20 & & & & & 12.65 & 42.2 \\
\hline July 1 & & ot, & in & & & & & & & 5.03 & 6.82 & 5.40 & & & & 17.25 & \\
\hline to & 92 & $\mathrm{ER}$ & in & & & & & & & 1.49 & 1.68 & 1.79 & & & & 4.96 & \\
\hline September 30 & & NIR, & in & & & & & & & 3.54 & 5.14 & 3.61 & & & & 1.2 .29 & 40.9 \\
\hline August 1 & & CU, & in & & & & & & & & 4.96 & 6.40 & 5.24 & & & 16.59 & \\
\hline to & 92 & $\mathrm{ER}$, & in & & & & & & & & 1.46 & 1.89 & 1.83 & & & 5.18 & \\
\hline October 31 & & NIR, & in & & & & & & & & 3.50 & 4.51 & 3.41 & & & 11.41 & 38.0 \\
\hline September 1 & & $\mathrm{CU}$ & in & & & & & & & & & 4.42 & 6.24 & 4.77 & & 15.43 & \\
\hline to & 9 & ER, & in & & & & & & & & & 1.59 & 1.94 & 2.11 & & 5.64 & \\
\hline November 30 & & NIR, & in & & & & & & & & & 2.84 & 4.30 & 2.65 & & 9.79 & 32.6 \\
\hline October 1 & & $\mathrm{CU}$, & in & & & & & & & & & & 4.56 & 5.70 & 4.49 & 14.74 & \\
\hline & 92 & ER, & in & & & & & & & & & & 1.74 & 2.23 & 2.27 & 6.24 & \\
\hline December 31 & & NIR, & in & & & & & & & & & & 2.82 & 3.47 & 2.21 & 8.50 & 28.3 \\
\hline November 1 & & $\mathrm{CU}$ & in & 4.39 & & & & & & & & & & 3.93 & 5.38 & 13.66 & \\
\hline to & 92 & $\mathrm{ER}$ & in & 1.56 & & & & & & & & & & 1.87 & 2.38 & 5.81 & \\
\hline January 81 & & $\mathrm{NIR}$, & in & 2.83 & & & & & & & & & & 2.07 & 2.95 & 7.84 & 26.1 \\
\hline December 1 & & $\mathrm{cU}$ & in & 5.17 & 3.96 & & & & & & & & & & 4.01 & 13.14 & \\
\hline to & 90 & $\mathrm{ER}$, & in & 1.63 & 0.99 & & & & & & & & & & 2.11 & 4.73 & \\
\hline February 28 & & NIR, & in & 3.54 & 2.97 & & & & & & & & & & 1.90 & 8.41 & 28.0 \\
\hline
\end{tabular}

$\mathrm{CU} \equiv$ Consumptive use, $\mathrm{ER}=$ Effective rainfall, $\mathrm{NIR}=$ Net irrigation requirement, $(\mathrm{CU}-\mathrm{ER}) \quad *=$ Recommended planting date. 
dry season yield depending upon crop duration, variety, management and location.

This study estimated monthly consumptive use (CU) of water by rice in the humid and semiarid regions of Puerto Rico. Arecibo in the humid north coast and Lajas in the semiarid south coast of Puerto Rico were selected to represent rice producing regions.

\section{MATERIALS AND METHODS}

Crop duration of 90,105 and 120 days and 12 planting dates were considered in this study. Table 1 summarizes variables that affect consumptive use and irrigation requirements. Monthly consumptive use (CU) by rice was estimated with climatic data $(1,5)$, computer model (2) and the following relationship:

$\mathrm{CUm}=\left(\mathrm{K}_{e} \times \mathrm{K}_{\mathrm{t}} \times \mathrm{p} \times \mathrm{T} \times \mathrm{H}\right) / 100$ /1)

where CUm $=$ monthly consumptive use (inches), $\mathrm{K}_{\mathrm{t}}=\mathbf{a}$ climatic coefficient which is related to mean air temperature, $p=$ monthly percentage of daylight hours in the year $(7), \mathrm{T}=$ mean air temperature in ${ }^{\circ} \mathrm{F}, \mathrm{H}=$ humid area factor of 0.8 and $\mathrm{K}_{\mathrm{c}}=$ crop coefficient reflecting growth stage (7). Average $K_{c}$ was 0.98 for 90 -day, 0.95 for 105 -day and 0.96 for 120-day-old crop.

Monthly $K_{c}(7,9)$ was assumed as follows:

\begin{tabular}{lccc} 
Days & \multicolumn{4}{c}{ Crop cycle, days } \\
\cline { 2 - 4 } & 90 & 105 & 120 \\
\hline $0-30$ & 0.86 & 0.67 & 0.67 \\
$31-60$ & 1.12 & 1.11 & 1.10 \\
$61-90$ & 0.95 & 1.08 & 1.10 \\
$91-105$ & - & 0.95 & - \\
$91-120$ & - & - & 0.95
\end{tabular}

Monthly CUm was then added and multiplied by 25.4 to obtain total $\mathrm{CU}$ in $\mathrm{mm}$.

\section{RESULTS AND DISCUSSION}

Tables 2 and 7 indicate consumptive use (CUm, inches) for 12 planting dates and three crop lengths of $3,3^{1 / 2}$ and 4 months at Arecibo and Lajas, Puerto Rico. Table 8 gives seasonal consumptive use (CU, $\mathrm{mm}$ ) of rice for 12 planting dates and three crop seasons at these two locations.

For four-month crop and December planting, monthly CU varied from 787 to $1298 \mathrm{~mm}$ at Arecibo (table 4) and from 750 to $1255 \mathrm{~mm}$ at Lajas (table 7). CU was maximum for May planting and minimum for November planting.

For all 12 planting dates at Arecibo, seasonal CU range was 334-451 $\mathrm{mm}$ for 90 days, $390-524 \mathrm{~mm}$ for 105 days, $442-589 \mathrm{~mm}$ for 120 days at 
TABLE 3.-Net irrigation requirements (inches per month) with modified Blaney-Criddle method. Crop: Rice. Location: Arecibo

\begin{tabular}{|c|c|c|c|c|c|c|c|c|c|c|c|c|c|c|c|c|c|}
\hline $\begin{array}{l}\text { Planting to } \\
\text { last harvest }\end{array}$ & Days & Pamamet & & $\operatorname{Jan}$ & Feb & Mar & April & May & June & July & Aug & Sept & Oet & Nov & Dee & Total & $\begin{array}{c}\text { Gross } \\
\text { irrigation }\end{array}$ \\
\hline January 1 & & CU, & in & 3.47 & 4.60 & 5.28 & 2.45 & & & & & & & & & 15.81 & \\
\hline to & 105 & $\mathrm{ER}$ & in & 0.82 & 1.02 & 0.98 & 1.41 & & & & & & & & & 4.23 & Flood \\
\hline April 15 & & NIR, & in & 2.65 & 3.58 & 4.80 & 1.04 & & & & & & & & & 11.56 & 38.5 \\
\hline February 1 & & CU, & in & & 2.67 & 5.47 & 5.53 & 2.76 & & & & & & & & 16.43 & \\
\hline to & 104 & ER, & in & & 1.16 & 0.99 & 1.67 & 1.61 & & & & & & & & 5.44 & \\
\hline May 15 & & NIR, & in & & 1.50 & 4.48 & 3.86 & 1.15 & & & & & & & & 10.99 & 36.6 \\
\hline March 1 & & CU, & in & & & 3.48 & 5.72 & 6.45 & 2.97 & & & & & & & 18.62 & \\
\hline to & 107 & ER, & in & & & 0.93 & 1.69 & 1.98 & 1.41 & & & & & & & 6.01 & \\
\hline June 15 & & NIR, & in & & & 2.55 & 4.09 & 4.46 & 1.56 & & & & & & & 12.60 & 42.0 \\
\hline April 1 & & $\mathrm{CU}$ & in & & & & 3.45 & 6.69 & 6.72 & 2.84 & & & & & & 19.71 & \\
\hline to & 106 & $\mathrm{ER}$, & in & & & & 1,21 & 2.01 & 1.73 & 1.24 & & & & & & 6.19 & \\
\hline July 15 & & NIR, & in & & & & 2.24 & 4.68 & 4.99 & 1.60 & & & & & & 13.52 & 45.1 \\
\hline May 1 & & $\mathrm{CU}$ & in & & & & & 4.24 & 6.94 & 6.68 & 2.80 & & & & & 20.63 & \\
\hline to & 107 & ER, & in & & & & & 1.65 & 1.76 & 1.58 & 1.34 & & & & & 6.29 & \\
\hline August 15 & & NIR, & in & & & & & 2.59 & 5.21 & 5.09 & 1.46 & & & & & 14.35 & 47.8 \\
\hline June 1 & & $\mathrm{CU}$ & in & & & & & & 4.17 & 6.88 & 6.53 & 2.71 & & & & 20.29 & \\
\hline to & 107 & $\mathrm{ER}$, & in & & & & & & 1.62 & 1.56 & 1.65 & 1.54 & & & & 6.36 & \\
\hline September 15 & & NIR, & in & & & & & & 2.55 & 5.32 & 4.88 & 1.17 & & & & 13.93 & 46.4 \\
\hline July 1 & & $\mathrm{CU}$ & in & & & & & & & 4.40 & 6.79 & 6.12 & 2.55 & & & 19.86 & \\
\hline to & 107 & $\mathrm{ER}$, & in & & & & & & & 1.44 & 1.67 & 1.86 & 1.58 & & & 6.55 & \\
\hline October 15 & & NIR, & in & & & & & & & 2.96 & 5.11 & 4.26 & 0.98 & & & 13.31 & 44.4 \\
\hline August 1 & & CU, & in & & & & & & & & 4.34 & 6.36 & 5.97 & 2.41 & & 19.08 & \\
\hline to & 107 & ER, & in & & & & & & & & 1.41 & 1.89 & 1.91 & 1.85 & & 7.06 & \\
\hline November 15 & & NIR, & in & & & & & & & & 2.93 & 4.47 & 4.06 & 0.56 & & 12.02 & 40.1 \\
\hline September 1 & & $\mathrm{CU}$ & in & & & & & & & & & 3.87 & 6.20 & 5.46 & 2.20 & 17.73 & \\
\hline to & 106 & ER, & in & & & & & & & & & 1.54 & 1.93 & 2.20 & 2.00 & 7.67 & \\
\hline December 15 & & NIR, & in & & & & & & & & & 2.33 & 4.27 & 3.26 & 0.20 & 10.06 & 33.5 \\
\hline October 1 & & $\mathrm{OU}$ & in & 2.14 & & & & & & & & & 3.99 & 5.66 & 5.11 & 16.89 & \\
\hline to & $10 \pi$ & $\mathrm{ER}$, & in & 1.88 & & & & & & & & & 1.69 & 2.22 & 2.35 & 7.64 & \\
\hline January 15 & & NIR, & in & 0.76 & & & & & & & & & 2.30 & 3.44 & 2.75 & 9.25 & 30.8 \\
\hline November 1 & & CU, & in & 4.96 & 2.11 & & & & & & & & & 3.45 & 5.30 & 15.82 & \\
\hline to & 107 & $\mathrm{ER}$ & in & 1.61 & 0.89 & & & & & & & & & 1.82 & 2.38 & 6.70 & \\
\hline February 15 & & NIR, & in & 3.35 & 1.22 & & & & & & & & & 1.63 & 2.92 & 9.12 & 30.4 \\
\hline December 1 & & CU, & in & 5.16 & 4.42 & 2.26 & & & & & & & & & 3.50 & 15.34 & \\
\hline to & 105 & $\mathrm{ER}$ & in & 1.63 & 1.01 & 0.88 & & & & & & & & & 2.05 & 5.52 & \\
\hline March 15 & & NIR, & in & 5.58 & 3.41 & 1.43 & & & & & & & & & 1.45 & 9.82 & 32.7 \\
\hline
\end{tabular}


TABLE 4.-Net irrigation requirements (inehes per month) with modified Blaney-Criddle method. Crop: Rice. Location: Arecibo

\begin{tabular}{|c|c|c|c|c|c|c|c|c|c|c|c|c|c|c|c|c|c|}
\hline $\begin{array}{l}\text { Planting to } \\
\text { last harvest }\end{array}$ & Days & Paramet & & $\mathrm{Jan}$ & Feb & Mar & April & May & June & duly & Aug & Sept & Oet & Nov & Dec & Total & $\begin{array}{c}\text { Gross } \\
\text { irrigation }\end{array}$ \\
\hline January 1 & & $\mathrm{CU}$ & in & 3.09 & 4.54 & 5.39 & 4.95 & & & & & & & & & 17.96 & \\
\hline to & 120 & $\mathbf{E R}$ & in & 0.80 & 1.02 & 0.99 & 1.62 & & & & & & & & & 4.43 & Flood \\
\hline April 30 & & $\mathrm{NIR}$, & in & 2.29 & 3.52 & 4.40 & 3.33 & & & & & & & & & 13.53 & 45.1 \\
\hline February 1 & & CU, & in & & 2.36 & 5.38 & 5.64 & 5.77 & & & & & & & & 19.16 & \\
\hline to & 120 & $\mathrm{ER}$ & in & & 1.14 & 0.99 & 1.68 & 1.91 & & & & & & & & 5.72 & \\
\hline May 31 & & NIR, & in & & 1.22 & 4.40 & 3.96 & 8.86 & & & & & & & & 13.43 & 44.8 \\
\hline March 1 & & $\mathrm{CU}$ & in & & & 3.11 & 5.65 & 6.58 & 5.97 & & & & & & & 21.31 & \\
\hline to & 122 & $\mathrm{ER}$ & in & & & 0.91 & 1.69 & 2.00 & 1.66 & & & & & & & 6.26 & \\
\hline June 30 & & NIR, & in & & & 2.20 & 3.96 & 4.59 & 4.31 & & & & & & & 15.05 & 50.2 \\
\hline April 1 & & $\mathrm{CU}$ & in & & & & 3.06 & 6.61 & 6.87 & 5.89 & & & & & & 22.42 & \\
\hline to & 122 & ER, & in & & & & 1.18 & 2.00 & 1.75 & 1.47 & & & & & & 8.40 & \\
\hline July 31 & & NIR, & in & & & & 1.88 & 4.61 & 5.12 & 4.41 & & & & & & 16.02 & 53.4 \\
\hline May 1 & & $\mathrm{CU}$ & in & & & & & 3.76 & 6.88 & 6.77 & 5.78 & & & & & 23.19 & \\
\hline to & 123 & $\mathrm{ER}$, & in & & & & & 1.61 & 1,75 & 1.55 & 1.58 & & & & & 6.49 & \\
\hline August 31 & & $\mathrm{NIR}$, & in & & & & & 2.15 & 5.13 & 5.23 & 4.20 & & & & & 16.71 & 55.7 \\
\hline June 1 & & $\mathrm{CU}$ & in & & & & & & 3.73 & 6.79 & 6.67 & 5.40 & & & & 22.59 & \\
\hline to & 122 & ER, & in & & & & & & 1.58 & 1.55 & 1.66 & 1.79 & & & & 6.58 & \\
\hline September 30 & & $\mathrm{NIR}$ & in & & & & & & 2.15 & 5.25 & 5.01 & 3.61 & & & & 16.01 & 58.4 \\
\hline July 1 & & CU, & in & & & & & & & 3.90 & 6.71 & 6.26 & 5.24 & & & 22.11 & \\
\hline to & 123 & ER, & in & & & & & & & 1.40 & 1.67 & 1.88 & 1.83 & & & 6.77 & \\
\hline October 31 & & NIR, & in & & & & & & & 2.50 & 5.04 & 4.38 & 3.41 & & & 15.33 & 51.1 \\
\hline August 1 & & CU, & in & & & & & & & & 3.87 & 6.28 & 6.09 & 4.77 & & 21.01 & \\
\hline to & 122 & $E R$, & in & & & & & & & & 1.37 & 1.88 & 1.92 & 2.11 & & 7.29 & \\
\hline November 30 & & NIR, & in & & & & & & & & 2.50 & 4.40 & 4.17 & 2.65 & & 13.73 & 45.8 \\
\hline September 1 & & $\mathrm{CU}$, & in & & & & & & & & & 3.43 & 6.12 & 5.58 & 4.49 & 19.62 & \\
\hline to & 122 & $\mathrm{ER}$, & in & & & & & & & & & 1.50 & 1.92 & 2.21 & 2.27 & 7.916 & \\
\hline December 31 & & NIR, & in & & & & & & & & & 1.98 & 4.20 & 3.37 & 2.21 & 11.71 & 39.0 \\
\hline October I & & CU, & in & 4.89 & & & & & & & & & 3.54 & 5.59 & 5.22 & 18.73 & \\
\hline to & 123 & $\mathrm{ER}$, & in & 1.56 & & & & & & & & & 1.64 & 2.21 & 2.37 & 7.70 & \\
\hline January 31 & & NIR, & in & 2.83 & & & & & & & & & 1.89 & 3.37 & 2.85 & 10.94 & 36.5 \\
\hline November 1 & & $\mathrm{CU}$ & in & 5.06 & 3.96 & & & & & & & & & 3.13 & 5.25 & 17.39 & \\
\hline to & 120 & $\mathrm{ER}$ & in & 1.62 & 0.99 & & & & & & & & & 1.79 & 2.37 & 6.77 & \\
\hline February 28 & & NIR, & in & 3.44 & 2.97 & & & & & & & & & 1.34 & 2.88 & 10.62 & 35.4 \\
\hline December 1 & & $\mathrm{CU}$ & in & 5.11 & 4.53 & 4.71 & & & & & & & & & 3.10 & 17,44 & \\
\hline to & 121 & $\mathrm{ER}$, & in & 1.69 & 1.02 & 0.95 & & & & & & & & & 2.01 & 5.60 & \\
\hline March 31 & & NIR, & in & 3.48 & 3.51 & 3.76 & & & & & & & & & 1.09 & 11.84 & 39.5 \\
\hline
\end{tabular}


TABLE 5.-Net irrigation requirements (inches per month) with modified Blaney-Criddle method. Crop: Rice. Location: Lajas

\begin{tabular}{|c|c|c|c|c|c|c|c|c|c|c|c|c|c|c|c|c|c|}
\hline $\begin{array}{l}\text { Planting to } \\
\text { last harvest }\end{array}$ & Days & Paramet & & $\mathrm{Jan}$ & Feb & Mar & April & May & Jume & July & Aug & Sept & Oet & Nov & Dec & Total & $\begin{array}{c}\text { Gross } \\
\text { irrigation }\end{array}$ \\
\hline Jamuary 1 & & $\mathrm{CU}$, & in & 8.84 & 4.53 & 4.58 & & & & & & & & & & 12,95 & \\
\hline to & 90 & $\mathrm{ER}$ & in & 0.41 & 0.55 & 0.65 & & & & & & & & & & 1.60 & Flood \\
\hline March 31 & & NIŔ, & in & 8.44 & 3.98 & 3.98 & & & & & & & & & & 11.35 & 37.8 \\
\hline February & & cU, & in & & 2.98 & 5.33 & 4.88 & & & & & & & & & 13.19 & \\
\hline to & 89 & ER, & in & & 0.61 & 0.68 & 1.25 & & & & & & & & & 2.55 & \\
\hline April 30 & & NIR, & in & & 2.37 & 9.65 & 3.63 & & & & & & & & & 10.64 & 35.5 \\
\hline March 1 & & $\mathrm{CU}$ & in & & & 3.86 & 5.67 & 5.74 & & & & & & & & 15.28 & \\
\hline to & 92 & $\mathbf{E R}$ & in & & & 0.59 & 1.31 & 1.36 & & & & & & & & 3.26 & \\
\hline May 31 & & $\mathrm{NIR}$ & in & & & 3.27 & 4.36 & 4.38 & & & & & & & & 12.02 & 40.1 \\
\hline April 1 & & $\mathrm{CU}$ & in & & & & 3.87 & 6.71 & 5.93 & & & & & & & 16.51 & \\
\hline to & 91 & ER, & in & & & & 0.92 & 1.43 & 0.99 & & & & & & & 3.35 & \\
\hline June 30 & & $\mathrm{NIR}$, & in & & & & 2.95 & 5.28 & 4.94 & & & & & & & 13.16 & 43.9 \\
\hline May 1 & & CU, & in & & & & & 4.81 & 6.99 & 5.74 & & & & & & 17.55 & \\
\hline to & 92 & ER, & in & & & & & 1.26 & 1.05 & 1.33 & & & & & & 3.65 & \\
\hline July 31 & & NIR, & in & & & & & 3.55 & 5.94 & 4.41 & & & & & & 13.90 & 46.3 \\
\hline June 1 & & $\mathrm{CU}$, & in & & & & & & 4.74 & 6.78 & 5.58 & & & & & 17.10 & \\
\hline to & 92 & $\mathrm{ER}$ & in & & & & & & 1.11 & 1.41 & 2.13 & & & & & 4.65 & \\
\hline August 31 & & NIR, & in & & & & & & 3.64 & 5.37 & 3.44 & & & & & 12.44 & 41.5 \\
\hline July 1 & & $\mathrm{CU}$, & in & & & & & & & 4.94 & 6.57 & 5.23 & & & & 16.74 & \\
\hline to & 92 & $\mathrm{ER}$, & in & & & & & & & 1.13 & 2.26 & 2.47 & & & & 5.85 & \\
\hline September 30 & & NIR, & in & & & & & & & 3.81 & 4.32 & 2.76 & & & & 10.89 & 36.3 \\
\hline August 1 & & $\mathrm{CU}$ & in & & & & & & & & 4.79 & 6.20 & 5.09 & & & 16.08 & \\
\hline to & 92 & ER, & in & & & & & & & & 1.68 & 2.61 & 2.02 & & & 6.30 & \\
\hline October 31 & & NIR, & in & & & & & & & & 3.11 & 3.59 & 3.07 & & & 9.77 & 32.6 \\
\hline September I & & CU, & in & & & & & & & & & 4.28 & 6.07 & 4.68 & & 14.98 & \\
\hline to & 9 & $\mathbf{E R}$ & in & & & & & & & & & 2.16 & 2.13 & 1.60 & & 5.89 & \\
\hline November 30 & & NIR, & in & & & & & & & & & 2.12 & 3.94 & 3.03 & & 9.08 & 30.3 \\
\hline Oetober 1 & & $\mathrm{CU}$ & in & & & & & & & & & & 4.43 & 5.54 & 4.34 & 14.31 & \\
\hline to & 92 & ER, & in & & & & & & & & & & 2.14 & 1.68 & 0.99 & 4.81 & \\
\hline December 31 & & NIR, & in & & & & & & & & & & 2.29 & 3.85 & 3.35 & 9.49 & 31.6 \\
\hline November 1 & & $\mathrm{CU}$ & in & 4.26 & & & & & & & & & & 3.83 & 5.16 & 13.24 & \\
\hline & 92 & $\mathrm{ER}$ & in & 0.78 & & & & & & & & & & 1.69 & 1.03 & 3.51 & \\
\hline January 31 & & NIR, & in & 3.48 & & & & & & & & & & 2.14 & 4.13 & 9.74 & 32.5 \\
\hline December 1 & & $\mathrm{CU}$ & in & 5.00 & 3.86 & & & & & & & & & & 3.89 & 12.74 & \\
\hline to & 90 & $\mathrm{ER}$ & in & 0.81 & 0.53 & & & & & & & & & & 1.24 & 2.58 & \\
\hline February 28 & & NIR, & in & 4.18 & 3.34 & & & & & & & & & & 2.64 & 10.16 & 33.9 \\
\hline
\end{tabular}


Lajas; 324-446 mm for 90 days, 378-516 mm for 105 days, $428-579 \mathrm{~mm}$ for 120 days. Average seasonal $\mathrm{CU}(\mathrm{mm} / \mathrm{season})$ was 392 at Arecibo and 382 at Lajas for 90 days; 458 at Arecibo and 447 at Lajas for 105 days; and 514 at Arecibo and 502 at Lajas for 120 days. Daily consumptive use was lower at Lajas and varied from 4.2 to $4.4 \mathrm{~mm} / \mathrm{day}$. These results agree with those of Silva et al, (6) and Ravalo et al. (5) in these areas. Silva (6) indicated a consumptive use of 3.1 to $8.4 \mathrm{~mm} /$ day in Vega Baja, P.R. Ravalo (5) found average consumptive use of $4.77 \mathrm{~mm} /$ day with the Thornthwaite PET Model. Yoshida (9) has shown that the Thornthwaite method overestimates PET by 10 to $15 \%$ compared to the Blaney-Criddle model. Yoshida (9) has indicated average consumptive use of $4 \mathrm{~mm} /$ day for a paddy field in the Phillipines. Experiments at International Rice Research Institute (9) resulted in a daily CU of $4.4 \mathrm{~mm} /$ day for the dry season. Our results are within these ranges.

It is cautioned that these CU in tables 2 to 8 have not been verified with lysimetex studies. Such extensive experimental data are not available for Puerto Rico. Experimental research to determine $\mathrm{K}_{\mathrm{c}}$ in Puerto Rico is lacking. These CU values were estimated with $K_{c}$ corresponding to areas similar to Puerto Rico. The following procedure is suggested as a guide:

1. Consult an extension agent for crop duration, planting season, location, and other management practices for rice production.

2. Select crop season and planting date in tables 2 to 8 closest to recommended practices.

3. Select values of CU corresponding to data in step 2.

The following examples indicate how to utilize CU for irrigation requirements.

Example 1: Estimate total CU for a paddy crop in Lajas area. Use average $K_{c}$ of 0.98 instead of 0.96 for a 4 -month-old crop and consider planting on 1 December.

From tables 7 and 8, CU is $431 \mathrm{~mm}$ with $\mathrm{K}_{\mathrm{c}}$ of 0.96 and 1 December planting. CU at Lajas $=(431 / .96) \times 0.98=440 \mathrm{~mm}$ during the growing season.

This example shows how to estimate CU with a new $\mathrm{K}_{\mathrm{c}}$.

Example 2: Estimate monthly net irrigation requirement with the data in table 1 .

Monthly effective rainfall (ERm) and net irrigation requirements (NIR) were estimated with the computer program (2) and with equations (2, 7):

$$
\begin{aligned}
& \mathrm{ERm}=\left(0.70917 \times \mathrm{I}^{0.82416}-0.11556\right) \times 10^{0.02426 \mathrm{cum}} \times \mathrm{f} \ldots \ldots \ldots / 2 / \\
& \mathrm{f}=0.531747+0.295164 \times \mathrm{D}-0.057697 \times \mathrm{D}^{2}+0.003804 \times \mathrm{D}^{3} \quad / 3 /
\end{aligned}
$$

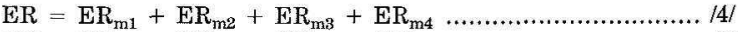

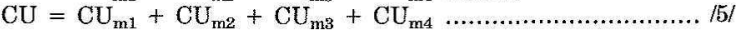


TABLE 6.-Net imigation requirements (inches per month) with modified Blaney-Criddle method. Crop: Rice. Location: Lajas

\begin{tabular}{|c|c|c|c|c|c|c|c|c|c|c|c|c|c|c|c|c|c|}
\hline $\begin{array}{l}\text { Planting to } \\
\text { last harvest }\end{array}$ & Days & Paramet & & Jan & $\mathrm{Feb}$ & Mar & April & May & June & July & Aug & Sept & oct & Nov & Dee & Total & $\begin{array}{l}\text { Gross } \\
\text { imrigation }\end{array}$ \\
\hline January 1 & & $\mathrm{CU}$ & in & 8.85 & 4.50 & 5.12 & 2.41 & & & & & & & & & 15.38 & \\
\hline to & 105 & ER, & in & 0.39 & 0.55 & 0.67 & 1.09 & & & & & & & & & 2.71 & Flood \\
\hline April 15 & & NIR, & in & 2.96 & 3.95 & 4.44 & 1.32 & & & & & & & & & 12.67 & 42.2 \\
\hline February 1 & & CU, & in & & 2.60 & 5.30 & 5.45 & 2.75 & & & & & & & & 16.09 & \\
\hline to & 104 & ER, & in & & 0.60 & 0.68 & 1.29 & 1.15 & & & & & & & & 8.72 & \\
\hline May 15 & & NIR, & in & & 2.00 & 4. 62 & 4.16 & 1.60 & & & & & & & & 12.37 & 41.2 \\
\hline March 1 & & $\mathrm{CU}$ & in & & & 3.38 & 5.64 & 6.42 & 2.95 & & & & & & & 18.39 & \\
\hline to & 107 & $\mathrm{ER}$, & in & & & 0.57 & 1.31 & 1.41 & 0.84 & & & & & & & 4.13 & \\
\hline June 15 & & NIR, & in & & & 2.81 & 4.33 & 5.01 & 2,11 & & & & & & & 14.26 & 47.5 \\
\hline April I & & $\mathrm{CU}$ & in & & & & 3.39 & 6.67 & 6.70 & 2.78 & & & & & & 19.54 & \\
\hline to & 106 & ER, & in & & & & 0.90 & 1.43 & 1.04 & 1.13 & & & & & & 4.49 & \\
\hline July 15 & & NIR, & in & & & & 2.49 & 5.24 & 5.67 & 1.65 & & & & & & 15.04 & 50.1 \\
\hline May 1 & & $\mathrm{CU}$ & in & & & & & 4.21 & 6.95 & 6.49 & 2.70 & & & & & 20.35 & \\
\hline to & 107 & $\mathrm{ER}$, & in & & & & & 1.22 & 1.05 & 1.39 & 1.82 & & & & & 5.48 & \\
\hline August 15 & & NIR, & in & & & & & 2.99 & 5.90 & 5.10 & 0.88 & & & & & 14.88 & 49.6 \\
\hline June 1 & & $\mathrm{CU}$ & in & & & & & & 4.16 & 6.74 & 6.29 & 2,62 & & & & 19.81 & \\
\hline to & 107 & $\mathrm{ER}$, & in & & & & & & 1.07 & 1.41 & 2.22 & 2.14 & & & & 6.84 & \\
\hline September 15 & & NIR, & in & & & & & & 3.08 & 5.33 & 4.07 & 0.49 & & & & 12.97 & 43.2 \\
\hline July 1 & & $\mathrm{CU}$ & in & & & & & & & 4.32 & 6.54 & 5.93 & 2.48 & & & 19.27 & \\
\hline to & 107 & $\mathrm{ER}$ & in & & & & & & & 1.09 & 2.25 & 2.57 & 1.74 & & & 7.65 & \\
\hline Oetober 15 & & NIR, & in & & & & & & & 3.23 & 4.29 & 3.36 & 0.74 & & & 11.62 & 38.7 \\
\hline August 1 & & $\mathrm{CU}$ & in & & & & & & & & 4.20 & 6.16 & 5.80 & 2.85 & & 18.50 & \\
\hline to & 107 & $\mathrm{ER}$, & in & & & & & & & & 1.68 & 2.60 & 2.10 & 1.41 & & 7.73 & \\
\hline November 15 & & NIR, & in & & & & & & & & 2.57 & 3.56 & 3.71 & 0.94 & & 10.77 & 35.9 \\
\hline September 1 & & $\mathrm{CU}$ & in & & & & & & & & & 3.75 & 6.03 & 5.31 & 2.13 & 17.21 & \\
\hline to & 106 & ER. & in & & & & & & & & & 2.10 & 2.12 & 1.66 & 0.87 & 6.76 & \\
\hline December 15 & & NIR, & in & & & & & & & & & 1.65 & 3.90 & 3.64 & 1.25 & 10.45 & 34.8 \\
\hline October 1 & & $\mathrm{CU}$ & in & 2.07 & & & & & & & & & 3.88 & 5.50 & 4.94 & 16.39 & \\
\hline to & 107 & ER, & in & 0.69 & & & & & & & & & 2.08 & 1.68 & 1.02 & 5.47 & \\
\hline January 15 & & NIR, & in & 1.38 & & & & & & & & & 1.80 & 3.82 & 3.92 & 10.92 & 36.4 \\
\hline November 1 & & $\mathrm{CU}$ & in & 4.79 & 2.06 & & & & & & & & & 3.35 & 5.13 & 15.34 & \\
\hline to & 107 & ER, & in & 0.80 & 0.48 & & & & & & & & & 1.65 & 1.03 & 3.96 & \\
\hline February 15 & & NIR, & in & 3.99 & 1.59 & & & & & & & & & 1.71 & 4.10 & 11.38 & 87.9 \\
\hline December 1 & & $\mathrm{CU}$ & in & 4.99 & 4.32 & 2.20 & & & & & & & & & 3.39 & 14.90 & \\
\hline to & 105 & $\mathrm{ER}$ & in & 0.81 & 0.54 & 0.57 & & & & & & & & & 1.21 & 3.18 & \\
\hline March 15 & & $\mathrm{NIR}$, & in & 4.17 & 3.78 & 1.63 & & & & & & & & & 2.18 & 11.76 & 39.2 \\
\hline
\end{tabular}

$\mathrm{CU}=$ Consumptive use, $\mathrm{ER}=$ Effective rainfall, $\mathrm{NIR}=\mathrm{Net}$ irrigation requirement, $(\mathrm{CU}-\mathrm{ER}) \quad *=$ Recommended planting date. 
TABLE 7.-Net irrigation requirements (inches per month) with modified Blaney-Criddle method. Crop: Rice. Location: Lajas

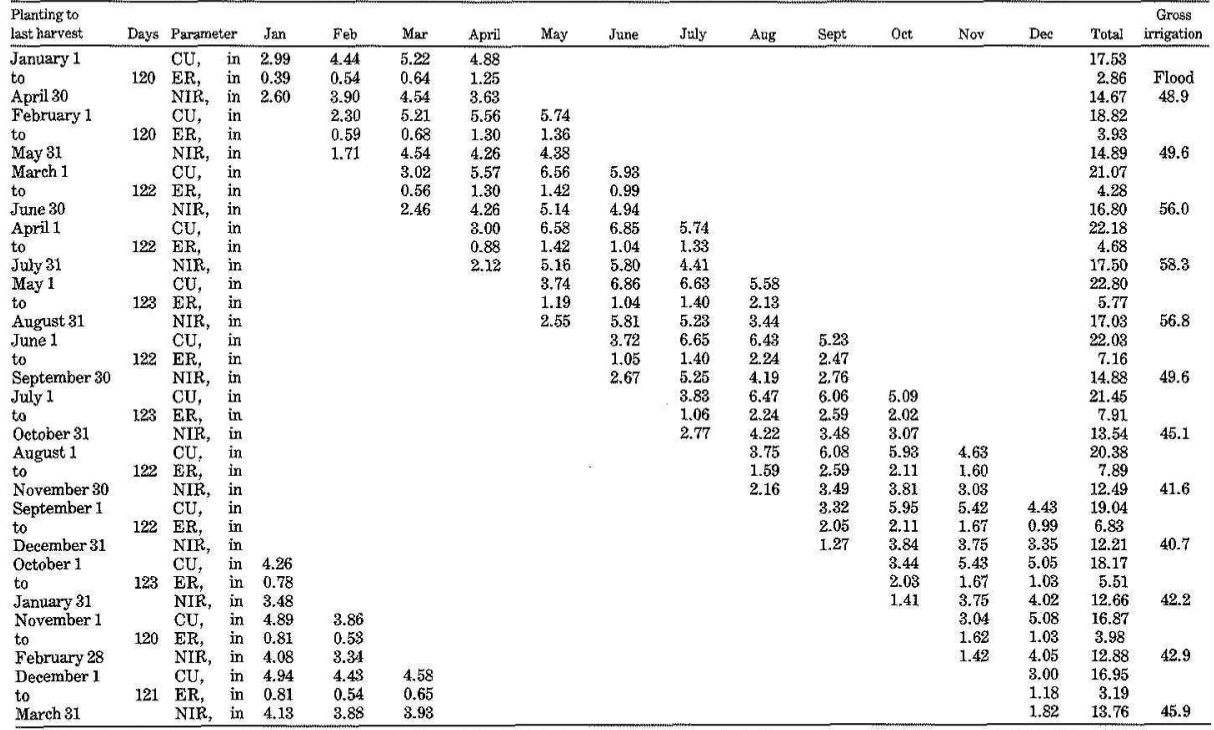




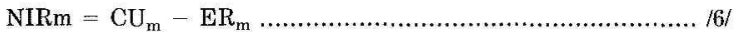

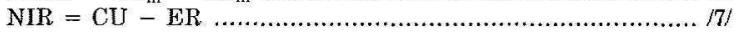

where $\mathrm{ER}_{\mathrm{m}}=$ monthly effective rainfall (inches); $\mathrm{I}=$ monthly rainfall (inches); $\mathrm{CU}_{\mathrm{m}}=$ given by equation $/ 1 /$ and tables 2 to $7 ; \mathrm{f}=$ correction factor; $\mathrm{D}=$ net depth of application (inches); $\mathrm{ER}=$ total effective rainfall (inches) obtained by summing $\mathrm{ER}_{\mathrm{m}}$ of first, second, third and fourth month, $\mathrm{CU}=$ total consumptive use (inches); $\mathrm{NIR}_{m}=$ monthly net irrigation requirement (inches); and $\mathrm{NIR}=$ total net irrigation requirement (inches).

Tables 2 to 7 indicate monthly effective rainfall (inches) and net irrigation requirements (inches) for twelve planting dates and three crop seasons of 90, 105 and 120 days at Arecibo and Lajas. These values are multiplied by 25.4 to obtain NIR in $\mathrm{mm}$. For 4 -month crop and twelve planting dates, total NIR tange was $270-424 \mathrm{~mm}$ at Arecibo and $310-445$ $\mathrm{mm}$ at Lajas. This is equivalent to $2.3-3.5 \mathrm{~mm} /$ day at Arecibo and 2.6 $-3.7 \mathrm{~mm} /$ day at Lajas.

Example 3: Estimate total gross water requirement for 12 planting dates and 3 crop lengths of 90,105 and 120 days for example 2.

Gross water requirement $(\mathrm{GIR}, \mathrm{mm})$ was estimated with $\mathrm{GIR}=(\mathrm{NIR}$ $\times 25.4) / 0.30$ where 0.30 represents an irrigation efficiency for flood irrigation system. Table 9 indicates total GIR of paddy at Arecibo and Lajas.

TABLE 8.-Total water consumption of rice in Arecibo and Lajas, Puerto Rico

\begin{tabular}{|c|c|c|c|c|c|c|}
\hline \multirow{4}{*}{ Planting date } & \multicolumn{6}{|c|}{ Seasonal eonsurnptive use, $\mathrm{mm}^{1}$} \\
\hline & \multicolumn{3}{|c|}{ Arecibo } & \multicolumn{3}{|c|}{ Lajas } \\
\hline & \multicolumn{6}{|c|}{ Crop season, months } \\
\hline & 3 & 3.5 & 4.0 & 3 & 3.5 & 4.0 \\
\hline January 01 & 338 & 401 & 456 & 329 & 392 & 445 \\
\hline February 01 & 343 & 417 & 487 & 335 & 409 & 478 \\
\hline March 01 & 394 & 473 & 541 & 388 & 467 & 585 \\
\hline April 01 & 423 & 501 & 569 & 419 & 496 & 563 \\
\hline May 01 & 451 & 524 & 589 & 446 & 516 & 579 \\
\hline June 01 & 443 & 515 & 574 & 434 & 503 & 559 \\
\hline July 01 & 438 & 504 & 562 & 425 & 489 & 545 \\
\hline August 01 & 421 & 485 & 584 & 408 & 470 & 518 \\
\hline September 01 & 392 & 450 & 498 & 380 & 437 & 484 \\
\hline October 01 & 374 & 429 & 476 & 363 & 416 & 462 \\
\hline November 01 & 347 & 402 & 442 & 336 & 390 & 428 \\
\hline December 01 & 334 & 390 & 443 & 324 & 378 & 431 \\
\hline Monthly average & 392 & 458 & 514 & 382 & 447 & 502 \\
\hline $\mathrm{mm} /$ day (average) & 4.4 & 4.4 & 4.3 & 4.2 & 4.3 & 4.2 \\
\hline
\end{tabular}

'Crop season includes 2 to 4 weeks for seedling establishment, 2 to 3 weeks after last inigation to allow harvest at reeommended moisture, and periad for permanent flooding. 
For 4-month crop, gross water requirement (table 9) varied from 899 to $1415 \mathrm{~mm}$ at Arecibo compared to $1034-1481 \mathrm{~mm}$ at Lajas during all 12 planting dates, respectively. Average total water requirement was 1164 $\mathrm{mm}$ at Arecibo, compared to $1223 \mathrm{~mm}$ at Lajas. Daily water requirement was $9.4-9.9 \mathrm{~mm} / \mathrm{day}$ at Arecibo compared to $9.9-10.4 \mathrm{~mm} /$ day at Lajas. These results agree with Silva et al. (6) and Ravalo et al. (5) in these areas. Silva et al. (6) indicated that a consumptive use of rice was 3.1 to $8.4 \mathrm{~mm} /$ day, and $1200 \mathrm{~mm}$ of total irrigation was required to produce a rice crop in Vega Baja, P.R. Ravalo and Goyal (5) found that a total water requirement of rice was $1396 \mathrm{~mm}$ (includes $20 \mathrm{~cm}$ for stand establishment) for a 122-day crop with a peak value of $12.4 \mathrm{~mm} /$ day in Lajas and daily water requirement ranged from 9.2 to $12.4 \mathrm{~mm} /$ day. Yoshida (9) has indicated $180 \mathrm{~mm}$ and $270 \mathrm{~mm}$ of monthly water requirement for wet season (June to December) and dry season (January to April) in the Philippines, respectively. He indicates that total water requirement of rice is $1200 \mathrm{~mm}$ with $200 \mathrm{~mm}$ for seedling establishment. The computed estimates are within these ranges.

TABLE 9.-Total water requirement of rice in Arecibo and Lajos, Puerto Rico

\begin{tabular}{|c|c|c|c|c|c|c|}
\hline \multirow{4}{*}{ Planting date } & \multicolumn{6}{|c|}{ Total water requirement (GIR), $\mathrm{cm}$ per season' } \\
\hline & \multicolumn{3}{|c|}{ Arecibo } & \multicolumn{3}{|c|}{ Lajas } \\
\hline & \multicolumn{6}{|c|}{ Crop season, months ${ }^{2}$} \\
\hline & 8 & 3.5 & 4.0 & 8 & 3.5 & 4.0 \\
\hline January 01 & 88.9 & 97.8 & 114.6 & 96.0 & 107.2 & 124.2 \\
\hline February 01 & 82.0 & 92.9 & 113.8 & 90.2 & 104.6 & 125.9 \\
\hline March 01 & 92.7 & 106.7 & 127.5 & 101.9 & 120.7 & 142.2 \\
\hline April 01 & 99.3 & 114.6 & 135.6 & 111.5 & 107.3 & 148.1 \\
\hline May 01 & 108.5 & 121.4 & 141.5 & 117.6 & 125.9 & 144.3 \\
\hline June 01 & 107.2 & 117.9 & 135.6 & 105.4 & 109.7 & 125.9 \\
\hline July 01 & 103.9 & 112.8 & 129.8 & 92.2 & 98.3 & 114.6 \\
\hline August 01 & 96.5 & 101.9 & 116.3 & 82.8 & 91.2 & 105.7 \\
\hline September 01 & 82.8 & 85.1 & 99.1 & 76.9 & 88.4 & 108.4 \\
\hline Oetober 01 & 71.9 & 78.2 & 92.7 & 80.3 & 92.5 & 107.2 \\
\hline November 01 & 66.3 & 77.2 & 89.9 & 82,6 & 96.3 & 108.9 \\
\hline December 01 & 71.1 & 88.1 & 100.3 & 86.1 & 99.6 & 116.6 \\
\hline Average & 89.3 & 99.1 & 116.4 & 93.6 & 103.5 & 122.3 \\
\hline $\mathrm{mm} /$ day (average) & 9.9 & 9.4 & 9.7 & 10.4 & 9.9 & 10.1 \\
\hline
\end{tabular}

${ }^{\mathrm{z}}$ Assumed an irrigation efficiency of $30 \%$ for flood irrigation.

$\mathrm{GIR}=(\mathrm{NIR} \times 2.54) /(0.80)$, where NIR values are from tables 2 to 7.

${ }^{2}$ Crop season includes 2 to 4 weeks for seedling establishment, 2 to 3 weeks after last irrigation to allow harvest at recommended moisture, and period for permanent flooding. 


\section{Example 4:}

Calculate monthly NIR, total NIR, total GIR of rice for the Lajas areas of Puerto Rico. Management factors are shown in Table 1. Consider planting in December and harvesting at the end of March. Assume an irrigation efficiency of $30 \%$ for flood irrigation.

Solution: Crop season - December 1 to March 31

Location - Lajas

Crop duration - 121 days

Management factors - Table 1

For these data, table 7 gives:

$\begin{array}{lccc} & \text { CU (in) } & \text { ER (in) } & \text { NIR (in) } \\ \text { December } & 3.00 & 1.18 & 1.82 \\ \text { January } & 4.94 & 0.81 & 4.13 \\ \text { February } & 4.43 & 0.59 & 3.88 \\ \text { March } & 4.58 & 0.65 & 3.93 \\ \text { Total } & 16.95 & 3.19 & 13.76\end{array}$

$$
\text { GIR }=\text { NIR/0.30 }=13.76 / 0.30=45.9 \text { inches }
$$

Total water requirement $=45.9 \times 25.4=1166 \mathrm{~mm}$

Daily water requirement $=1166 / 120=9.7 \mathrm{~mm} /$ day

or 1.13 litres/ha per sec

or $97 \mathrm{~m}^{3} /$ ha per day

This example shows procedure of how to utilize information in tables 2 to 9 to obtain total or daily water requirements for paddy rice.

\section{LITERATURE CITED}

1. Climatography of the United States No. 86-45 of Puerto Rico and U.S. Virgin Islands. In Climatic Survey of the U.S. Supplement. United States Department of Commerce, Washington, D.C.

2. Hackbart, C. A., 1987. Conuse and User's Manual. USDA-SCS, Fort Worth, TX.

3. Lozano, J. M. and F. Abruna, 1982. Season of the year on yields of seven medium-grain varieties of rice. J. Agric. Univ. P. R. 66 (3): 188-93.

4. and 1977. Effect of planting season on yield of eight short-grain varieties of rice under inigation. J. Agric. Univ. P. R. 61 (1): 6-10.

5. Ravalo, E. J. and M. R. Goyal, 1988. Water requirements of rice in Lajas Valley of Puerto Rico. Dimension CIAPR, 2 (8): 33-5.

6. Silva, S. and J. Vicente-Chandler, 1982, Water use by flooded rice in Puerto Rico. $J$. Agric. Univ. P. R. 66 (3): 181-87.

7. United States Department of Agriculture - Soil Conservation Serviee, 1970. Inigation Water Requirements. Eng. Tech. Div, Release 21. U. S. Govt. Printing Office, Washington, D. C. Pages 88 .

8. Vicente-Chandler, J., F. Abruñ, J. Lozano, S. Silva, A. Rodríguez and C. T. Ramírez, 1977. Cultivo intensivo y perspectivas del arroz en Puerto Rico. Bol. 250, Esta. Esp. Agrie., Univ. P. R., Rio Piedras, P. R.

9. Yoshida, S., 1981. Fundamentals of Rice Crop Seience. The International Rice Research Institute, Manila, Philippines. Pages 65-109. 
